\title{
The English Textbook. Tensions from an Intercultural Perspective
}

\author{
El libro de texto de inglés. Tensiones desde una \\ perspectiva intercultural
}

\author{
Astrid Nuñez-Pardo ${ }^{2 *}$ \\ Universidad Externado de Colombia
}

\begin{abstract}
This review article addresses tensions, critiques and trends that are still latent in mainstream research on English textbooks that have looked at their intercultural aspects, which need to be explored from the perspective of critical interculturality to resist the instrumental, regulatory, homogenizing and commercial nature of textbooks developed by foreign and local publishing houses. The manuscript firstly elaborates on the textbook as an object of research; secondly, it discusses critical analysis of the content of textbooks; and thirdly, the text concludes by pondering critical interculturality, as a decolonial alternative, to make possible the construction of criteria of being, knowledge and power to orient the development of the English textbook, and move away from a de-contextualised textbook toward a desirable contextualised one. This article encompasses the state of the art supporting an ongoing research study on the English textbook from the perspective of critical interculturality that is being conducted within the doctoral programme ${ }^{3}$ in Education at Universidad Pedagógica and Tecnológica de Colombia (UPTC), conducted during 20152018, and supported by Universidad Externado de Colombia, Bogotá.
\end{abstract}

Key words: English textbook, critical analysis, interculturality, critical interculturality

\section{Resumen}

Este artículo de revisión reporta las tensiones, críticas y tendencias latentes en el perfil de la investigación sobre los aspectos interculturales en los libros de texto de inglés, que necesitan indagarse desde la perspectiva de la interculturalidad

1 Received: March 1st 2018/ Accepted: September 4th 2018

2 astrid.nunez@uexternado.edu.co

3 Decolonising the English Textbook: A Venture from Critical Interculturality 
crítica para resistir la naturaleza instrumental, regulatoria, homogeneizante y comercial de los textos producidos por editoriales foráneas y locales. El documento, en primer lugar, justifica el libro de texto como objeto de estudio; en segundo lugar, discute el análisis crítico de contenido de los libros de texto; $\mathrm{y}$, en tercera instancia, concluye con la reflexión sobre la interculturalidad crítica, como alternativa decolonial, para posibilitar la construcción de criterios del ser, el saber y el poder que orienten el desarrollo del libro de texto deseable y contextualizando. El artículo corresponde al estado del arte de una investigación en curso acerca del libro de texto desde la perspectiva intercultural crítica, que se está realizado dentro del marco del doctorado en Educación de la Universidad Pedagógica y Tecnológica de Colombia (UPTC), con el apoyo por la Universidad Externado de Colombia, durante el período comprendido entre 2014-2018.

Palabras clave: Libro de texto de inglés, análisis crítico, interculturalidad, interculturalidad crítica

\section{Resumo}

Este artigo de revisão reporta as tensões, críticas e tendências latentes no perfil da pesquisa sobre os aspectos interculturais nos livros de texto de inglês, que necessitam indagar-se desde a perspectiva da interculturalidade crítica para resistir à natureza instrumental, regulatória, homogeneizante e comercial dos textos produzidos por editoriais forâneas e locais. O documento, em primeiro lugar, justifica o livro de texto como objeto de estudo; em segundo lugar, discute a análise crítica de conteúdo dos livros de texto; e, em terceira instância, conclui com a reflexão sobre a interculturalidade crítica como alternativa decolonial, para possibilitar a construção de critérios do ser, o saber e o poder que orientem o desenvolvimento do livro de texto desejável e contextualizando. $\mathrm{O}$ artigo corresponde ao estado da arte de uma pesquisa em curso acerca do livro de texto desde a perspectiva intercultural crítica, que se está realizado dentro do marco do doutorado em Educação da Universidade Pedagógica e Tecnológica da Colômbia (UPTC), com o apoio da Universidade Externado da Colômbia, durante o período compreendido entre 2014-2018.

Palavras chave: Livro de texto de inglês, análise crítica, interculturalidade, interculturalidade crítica 


\section{Introduction}

$\mathrm{E}$ nglish textbooks are not neutral as they not only depict and reproduce values, behaviours, cultural patterns, traditions and dominant ideologies, but they also reinforce stereotypes and support the idea that one nationality is superior to others. This supremacy of dominant cultures over dominated ones has been done through their written texts, oral discourses, iconography or activities proposed. It is also important to acknowledge that foreign and local English textbooks have privileged a predetermined static and monolithic vision of culture, marginalizing the diversity of local cultures. In addition to privileging examples of superficial culture (monastic, static, and admirable such as celebrations, tourist attractions, local gastronomy, etc.) over deep culture (dynamic, multifaceted, and with invisible and intricate definitions), the textbooks have decided on which discourses or ideologies to promote or hide and have hierarchised and poorly represented the different Western and non-Western ethnicities and cultures with a reductionist homogenised vision.

This has impeded the development of a critical consciousness (Freire, 1971, 1993) that results from individuals' intervention as transformers of the world they inhabit, toward transformative and heterogeneous cultural realities. In this way, the dominant discourse of knowledge, power and ways of being are legitimised, naturalised, and perpetuated. This has been supported by De Sousa Santos (2010, 2006) who has urged for studies to be conducted on the different aspects invisibilised by the hegemonic order.

The purpose of the study where this review comes from is to formulate the criteria to set the grounds for the development of a contextualised English textbook, conceived under critical interculturality, as a decolonial alternative, to overcome its uncritical development from the voices of Colombian teachers, authors and experts. It also contemplates the critical approaches of the postmethod, the understanding of the sociocultural local context, and the contextualisation and self-construction of pedagogical knowledge rooted in local demands (Kumaravadivelu, 2014, 2006, 2006a, 2006b,

232 2003, 2001, 1994). This article discusses the relevant research studies on English textbooks that have looked at their intercultural aspects and into the justification for the textbook to be treated as an object of research. 


\section{The textbook as an object of research}

Textbooks were first studied as objects of research in the European context. In 1975, the International Institute for Textbook Improvement (el Instituto Internacional para el Mejoramiento de los Libros de Texto) considered textbooks about History, Geography, Social Sciences, Politics and German, to analyse aspects such as self-image, the image of others, and education and development in the global era. Choppin (1992) was the first scholar that has referred to textbooks as objects of research because they "can be studied from different points of view, because they are a consumer product, a support for school-based knowledge, ideological and cultural vectors, and pedagogical instruments" (1992, p. 102). Likewise, García (1996) has reported that once World War II had ended, the United Nations Educational, Scientific and Cultural Organisation (UNESCO) entrusted the Georg Eckert Institute to revise the textbooks that had been published in Europe after World War I, to examine xenophobic contents and stereotypes that denigrated citizens from neighbouring countries.

In 1992, the School Manuals Projects (known as Proyecto Manuales Escolares - MANES) was created in Spain to study the school manuals that had been published in the country - between 1808 and 1990 - in partnership with universities from Spain and other countries (Villalaín, 2001; Ramírez, 2002). In this respect, Ramírez (2002) has pointed out that the collaboration between these two projects was formalised by a signed agreement in 1992 between the Instituto Nacional de Investigación Pedagógica -INIP [National Pedagogical Research Institute] and Educación Comparada de la Universidad Nacional de Educación a Distancia - UNED [The Compared Education at the Distance Learning National University] to promote scientific exchange and cooperation. Furthermore, the target geographical zone was broadened to include Portugal and Latin America with the creation of a university agreement to study school manuals, promoted by the MANES project. Other universities joined the project later. These included the Universidad de Cuyo (Argentina), Universidad de Antioquia (Colombia) and the Universidad Nacional Autónoma de México (UNAM). Later, other universities joined the agreement such as Universidad de la República (Uruguay), Universidades de La Plata, de Buenos Aires and de Entre Ríos (Argentina), Universidad Pedagógica Nacional de Bogotá (Colombia), the Pontifícia Universidad Católica de São Paulo (PUC-SP) and the Pontificia Universidad Católica de Quito (Ecuador). The Grupo de Investigadores Eleuterio Quintanilla, 1996) [Eleuterio Quintanilla research group] has confirmed that textbooks have been given a privileged place in the intercultural educational 
approaches, as they play a fundamental role in the teaching and learning processes; synthesise the proposed and transmitted culture; and create collective identities and express conflicts of interests.

In addition, Borre (1996) has commented that since the 1950s systematic research has been found about the ideological dimension of textbooks. According to the author, "An ideology is a system of values, stated more or less explicitly, that is constantly being defended and/ or attacked" (p. 111) and that is reflected, reproduced and transmitted in textbooks. Finally, the Instituto Internacional de Investigación Educativa para la Integración del Convenio Andrés Bello [International Educational Research Institute for Integration from the Andrés Bello Agreement], has been researching textbooks since 2009, and gathering relevant results about the conceptualisation of the research in this field, and the creation of an instrument to analyse textbooks and other materials used in the development of the teaching and learning processes (Mora, 2009; Mora \& Unzueta, 2012). Based on Moya's (2008) perspective, the textbook as an object of research, "Is given an outstanding place in the set of interests and commitments of educators in the field of educational research both in Europe and Latin América" (p. 137). Also, according to Negrín (2009), textbooks are "revealed as relentless thought-provoking sources and, simultaneously, as objects of multidisciplinary and complex study, which has generated a great diversity of research perspectives" (p. 187).

Following a consideration of textbooks as objects of research, below is a review of the research profile surrounding the analysis of English textbooks based on interculturality, a contemporary strand within EFL textbook and interculturality, both in the national and international spheres.

\section{Relevant studies about English textbooks in connection with interculturality}

Mainstream research on textbooks have analysed representations of racism, sexism, cultural representations, and dominant ideologies in subjects other than EFL, and have accounted for the ideologies and hidden agendas that the content of the textbooks has been spreading in the educational context. However, the prevailing tradition when researching English textbooks can be summarised into two general categories. The first tradition has included studies about their use and the related assessments of students and English language teachers. The second tradition is associated with the specific, critical and analytical research of the content of textbooks that has generated tensions 
regarding the different aspects involved in interculturality. These have included the ideologies, national identity, gender equality, culture and intercultural communicative competence, literacy practice fostered by the textbook, and social representations, carried out at both national and international levels that at times interrelate, overlap or coincide. They have been presented according to categories and have been organised thematically.

Identifying sexism and gender representations. Several authors have conducted studies about the relationship between language and sexism, among them Baiquiang (2008), Craeynest (2015), Dabbahg (2016), Datzman (2013), Ghorbani, (2009), Hall (2014), Hartman and Judd (1978), Hill (1980); Lee (2014), Lee and Collins (2008), Mukundan and Nimehchisalem (2008), Ndura (2010), Nofall and Qawar (2015), Pereira (2013), Porreca (1984), Rifkin (1998) and Syarifuddin (2014). The studies have focused on identifying gender discrimination through the analysis of contents using, among other aspects, the following categories: firstness, omission, visibility in readings and illustrations, as well as observable linguistic biases in the selection of nouns and adjectives associated with each gender. The common findings of these studies have confirmed that sexism has continued to flourish in English textbooks, since they have presented stereotyped visions of each gender. On the one hand, through the use of male images, which are mainly presented as utilising more sophisticated tools or performing more demanding tasks. On the other hand, the textbooks have not integrated the diversity of experiences in the lives of students from multicultural backgrounds and have presented stereotypes, invisibilities and unrealities.

Consequently, it is advisable for textbook writers and assessment committees to promote awareness of gender equality both in substantiated contents and in linguistic forms to minimise sexist biases in English textbooks. Furthermore, it is advisable for teachers and students to be aware of the hidden messages in these materials; to ensure they contribute to the empowerment of students so that they can identify their poorly constructed and represented lost voices; and to critically examine their life experiences and their relationship with others in their communities and the wider world, so that they can participate in the pursuit to transform the current world into a fair and equitable one.

The findings of these studies have given rise to the need for textbook authors to consider the criterion of gender equality, which is essential in the search for equality in diversity. This criterion should be 
reflected in the textbook contents, written passages, the representation of the characters' main roles, the titles and iconography, the professions and family roles, the attributes, and firstness, as well as in the male and female linguistic representations since they set a standard of interaction with others. It is important that textbooks show that differences are constituent elements of social heterogeneity, which if misrepresented or ignored, gives rise to discriminatory situations toward people of the opposite sex, thereby, undermining the promotion of rights and equity in diversity. The ideal textbook is inclusive in terms of gender equality, race diversity and ethnic groups to facilitate intercultural learning, which can be achieved through the formulation of criteria to guide the critical development of textbooks, based on the growing diversity of life experiences and cultures of students.

Discourses on otherness and Eurocentric knowledge. A study carried out by Spanish researcher Guijarro (2005) confirmed the research tendencies surrounding cultural and social values in relation to otherness and gender. These have been transmitted in a selection of seven textbooks, produced and used in Andalucía. His analysis has considered the explicit and implicit elements of the cultural/ethnic group and gender variables that are present in the iconography of passages and didactic activities. The purpose was to establish whether there were racist or sexist values, which were using the stereotypes and clichés surrounding these variables as a point of reference, and to raise awareness among foreign languages teachers about the presence of a hidden curriculum in the textbooks. The author has supported his research study with the evaluation that has been proposed by Cunningsworth (1995) about students' understanding of the social and cultural contexts of the textbook to evaluate the axiological, social and cultural potential they present. The findings have confirmed that locally produced textbooks represent, reproduce and perpetuate discourses of otherness, as a posture of geo-cultural, historic, archaeological, sociological and ethnological knowledge about others. This is centred on eurocentrism and, hence, on a hierarchy of cultures, where western cultures are superior to other cultures, and are taken as natural and legitimate scenarios for teaching English. They have given little attention to the diversity and to differences of otherness; and have superficially dealt with axiological aspects of gender and culture, since they have exclusively focused on grammar or on developing linguistic skills.

Yassine (2012) has analysed cultural conceptualisation in three textbooks which were produced in Algeria and used by secondary school students. The researcher has focused on culture, ideology, and 
otherness as constituents of the hidden curriculum, and has identified five types of cultures and the different ways in which they are visually and linguistically illustrated: national or local, target or foreign, global or international, from other English-speaking countries, and Western or European. The study had a manifold purpose which was to determine which was the most widely used in the English teaching context, to describe the representations of self and the other, and to observe their development or stagnation. To evaluate the textbooks, the researcher has developed the Multi-modal Semiotic Social Approach (MSSA), which involves the identification of linguistic texts and visual images, and their respective cultural contextualisation, for the purpose of capturing the linguistic, visual and semiotic components that articulate a social discourse based on specific ideologies. Furthermore, to inform the evaluation a questionnaire was administered to a group of secondary school teachers that used textbooks to gather information about the practical aspects of the books. The results revealed that all three textbooks included culturally loaded linguistic texts, with visual images containing strong connotative meanings that represented the five hierarchised types of cultures (national/local, target/foreign, international/ global, other English-speaking countries, and western European) and the reproduction of the discourses about the centre versus the periphery. Also, that British and American cultures are linguistically and visually privileged, and that they are being legitimised as the right context for English language teaching in Algeria. The international or global culture also played an important role, but it was mostly associated with Western or European cultures, rather than with the students' own national or local culture, or with those cultures from other English-speaking countries. Only one of the textbooks had made some references to the local/national culture, and the rest has only referred to it indirectly.

These studies have highlighted the need for generating an epistemological rupture from the Eurocentric vision in aspects of diversity, equality in difference, and culture and gender, which are intrinsic to building critical interculturality. Locally-produced textbooks have represented, reproduced and perpetuated epistemological, geocultural, historic, archaeological, sociological, and ethnological postures about "the other", centred on Eurocentrism and the hierarchisation of cultures, in which Western cultures are superior to others, and are taken as natural scenarios for teaching English. Furthermore, they have provided epistemological support, generated from other loci, for the assessment and interpretation of written texts and adjoining iconography to uncover knowledge about the diversity of phenomena in social life. 
De-contextualisation of knowledge and an uncritical approach as hegemony Aicega's (2007) critical analysis of a passage from an English textbook used in Argentina, has made it possible to assess its adaptation and ideological assumptions to the local context. The passage addresses diverse aspects of a renowned Puerto Rican singer such as his origin, professional career, and more especially his preferences and hobbies. The analysis has resorted to the explicative and descriptive observation criteria and has been framed within Freire's (1993) and Giroux and Mc Laren's (1994) critical pedagogy, which has been characterised by questioning and rejecting all forms of domination, with the purpose of establishing a discourse for social action and transformation of reality. It has also been underpinned by Fairclough's (1989) critical discourse analysis, leading to the discovery of hidden relationships between language, power, and ideology. The findings have revealed that the whole passage presented a flawless, categorically depicted, and idealised reality; and that it constructed all things Latino based on material wealth and individual success, popularity and a luxurious lifestyle. Everything that has been presented as familiar represents a totally alien reality to the text users and readers, and has evoked discourses from the mass media which are built around celebrities and trivialities. It has provided an increasing worldwide context of globalisation that replicates the disproportional relationship between the dominant and dominated cultures, which is not appropriate for teaching English in local settings.

Assuming that the knowledge contained in English textbooks legitimises an official understanding that has an impact on the construction of students' reality, researchers Di Franco, Siderac and Di Franco (2007) have analysed the type of citizenship generated by the uncritical approach in textbook editions (published after 2000) used in state-funded schools in Santa Rosa, Argentina, and which might provide the opportunity to break away from this logic. The study has revealed: (a) an important de-contextualisation of the knowledge presented, in terms of temporality, spatiality, and significance that has made it harder to construct relevant knowledge and critical citizenship; (b) the representation of the admirable culture (wise and inaccessible men), which has not considered the fact that economic matters imply a conflictive relationship between the production forces, politics, ideology, culture, and justice; (c) knowledge that has been presented as a privilege of a few, which refers to what Lander (2000) has defined as "colonisation of knowledge" (p. 53), attempting to naturalise and universalise the being, since other cultural and knowledge forms are considered ontologically inferior; (d) the absence of social conflicts due 
to the omission of contemporary leaders, and the inclusion of those from the past, but without deepening into their reasons for struggling; and (e) the absence of citizens' participation, since there are no communities or a sense of belonging, that can resist and fight for their rights (ethnic or racial groups, or members of the LGBT community). Contextualisation in these textbooks has been set in futile events, in a simple and harmonious world that is lacking political function, with incidence on the construction of knowledge and power. It seems that the construction of knowledge and the participation of citizens occur 'elsewhere', since knowledge has already been constructed, social conflicts have already been resolved, and some have still dared to suggest options for which citizens have the right to opt for. This is what for Lander (2000) has represented the most powerful expression of 'modern scientific thinking', in which the subject only has 'to be inserted', for the naturalisation of social relationships to take place.

The results have provided a warning sign on the decontextualisation of students' everyday life, the subject's disassociation from knowledge, contextual disengagement, and a total absence of local and experiential culture that have prevented the restructuring of the particular social schemes in which they are immersed. For Voloshinov (1992), this has meant not belonging to the spatial-temporal and semantic horizon, which is common to interlocutors. In other words, these textbooks are nothing but reproductions of predetermined knowledge. Researchers have suggested considering the possibility of critically transforming pedagogies (Torres, 1993) since English teachers, as knowledge generators, can dismantle the hegemony of a unique discourse to make room for reflection, transformation, and the construction of alternative knowledge.

These studies have emphasised on the need to unveil the latent relationships between language, power, and ideology through the analysis and treatment of social problems such as the social classes, gender, minority communities, sexual orientation, religion, language, etc. These are topics that should be considered in English textbooks to generate a debate and an intercultural, critical and emancipatory conscience - both on the part of students and on the part of English teachers.

Di Franco, Siderac and Di Franco (2007) have underlined the de-contextualisation of English textbooks and has supplied relevant theoretical support since it has reflected the colonisation of knowledge in them, substantiated by a lack of appropriateness to the teaching environment. They have depicted a predetermined knowledge and 
omitted the reflection and analysis of the economic, legal, political, ideological, and cultural aspects, which are intrinsic to the human beings and their everyday life. All of these are essential components of the critical interculturality that can be promoted through a contextualised English textbook.

Cultural component in texts, tasks and iconography. There are multiple studies that have analysed the cultural component in different dimensions; for instance, when balancing the contents of the target and local cultures; in their representation and treatment; or in the tendency to include elements from the deep or shallow cultures. The research involved include Ahmed and Narcy-Combes (2011), Aliakbari and Jamalvandi (2013), Amal Saleh, Javid and Rahimi (2010), Al-Obaidi (2015), Bahrami (2015), Bataineih (2009), Dehbozorgi, Amalsaleh and Kafipour (2015), Farzaneh, Kohandani and Nejadansaric (2014), Fuentes (2011), Habib (2014), Hussein Al Migdadi (2008), Jahan (2012), Kirkgöz and Ağçam (2011), Nguyen (2015), Reimann (2009), Rimani and Soleimani (2012), Thang Kiet (2009), Varón (2009), and Xiao (2010). All of these studies have utilised content analysis with the purpose of exploring the characteristics of the cultural content presented in English textbooks. For example, they have considered whether these texts include aspects from both the local and target cultures; if they focus on traditionally central cultures (the USA or the UK), or whether they involve aspects from peripheral cultures; and if culture is presented in a superficial way (Foods, Folklore, Festivals, Facts (Kramsch, 1993)). They have also considered if they describe elements from the deep culture.

On the other hand, they have also analysed the authenticity of cultural representations in textbooks. To analyse the cultural component, the authors have utilised their own checklists or some adapted versions from other researchers (Cortazzi \& Jin, 1999; Arias, Campo \& Zuluaga, 2001; Garinger, 2002, Miekley, 2005; and Ramírez \& Hall, 1990). The elements that have been found in these lists have gone from biases toward one culture or another, have established the link between the learners and the target cultures, as well as the balance regarding their representations. They have even found the attitude regarding stereotypes 240 and the contextualisation of the cultural content, both local and foreign, or the idealisation of the latter.

In general terms, the studies about the cultural component presented in English textbooks have concluded that there is a primacy of British and North American cultures, with a low frequency of the culture of origin and international cultures. The cultural content is 
presented out of context, based on models from Western and North American cultures, with characters that belong to the neutral cultures, in countries free of social problems for discussion. They contain characteristics, values, attitudes and stereotyped communication styles from dominant cultures, with no representative anchor or context to be validated, which has not allowed learners to make it relevant to their own cultural experiences and, thereby, develop their own cultural awareness. Only three of these studies, Bataneih (2009), Nguyen (2015), and Kirkgöz and Ağçam (2011) have found that the content in textbooks focused on students' local cultures, in comparison to the cultural references of foreign cultures. Studies have also suggested to both, authors and the editorial industry at large, for textbooks to be more open and flexible, with a balanced load of the different and real cultural content types; and to offer multiple possibilities for reflection, comparison and connection to elements of the learners' cultures (as a means to connect the content to real-life experiences), critical analysis, and the comprehension of diversity to promote cultural awareness. It is also advisable to include appropriate methods for teaching and learning about culture that facilitate the critical use of the materials and the questioning of their cultural content.

These researchers are in agreement with the current proposed assumption of textbooks disseminating cultural archetypes that create, perpetuate and naturalise the patterns and admirable, homogeneous, static, and monolithic cultural values of the Western hegemonic cultures (monocultural knowledge) in the recipient communities of these textbooks; thus, causing an adverse effect on intercultural knowledge by not exploiting the debating potential that cultural subjects have, which leads to the appreciation of worldwide cultural plurality. The studies have also established opposing and complementary binaries such as East-West, primitive-civilised, human-subhuman, magic/ mythic-scientific and traditional-modern regarding power; reasoningnon-reasoning and humanizing-dehumanizing coloniality in connection to being; and Eurocentrism-local knowledge in relation to knowledge (Walsh, 2009). They have illustrated the analysis of the textbooks with checklists from the cultural context in which the textbooks are to be used. They have also recommended for teachers and textbook authors to distance themselves from aimless and superficial assessment, centred on presentational aspects, and instead, to favour the analysis and the use of appropriate methods to teach and learn culture in a critical way, which are essential in the contextualisation of knowledge in textbooks, and in educating free-thinking, critical, autonomous people, who are aware and respectful of cultural diversity. 


\section{Intercultural aspects and intercultural communicative} competence. Aliakbari (2004) has analysed the representation of culture in 29 passages in four English textbooks produced in Iran, to determine whether they have developed Intercultural Communicative Competence (henceforth, ICC) in secondary school students. To analyse the content, Ramírez and Hall's (1990) checklist was used. This highlights the frequency and type of visual representation of culture. To establish the frequency, a code system which has defined the text as a basic unit of analysis has been created and six content analysis options were assigned: the word, the sense of the word, the sentence, the topic, the paragraph, and the text or complete passage. In addition, a new scheme has been established for new words and the meaning of each of these words has been considered as a unit of analysis since each sentence has a specific meaning, which is independent from the sentences that follow. Four sentence categories have been identified: sentences with no reference to culture, sentences with no reference to a specific culture, sentences referring to general culture, and sentences referring to a specific culture. Similarly, a code system with eight categories has been created for complete passages that were taken as units of analysis: reference to English-speaking countries, reference to non-English-speaking western countries, reference to Eastern countries, international comparison, reference to Iran, reference to Islam, reference to general texts, such as Science ones, and reference to reading passages with undefined identity.

The results have shown that, in all the four books, general reference to science, geography, historical events, and life stories are not centred on modus vivendi and that reading passages with no identity were the most frequent ones. The study has concluded that all the four textbooks shared the same orientation with a range between $72 \%$ and $85 \%$ of sentences with no references to a specific culture, and $13 \%$ of sentences in books 1, 2 and 3, and 4\% in book 4 with reference to general culture. Also, that cultural representations did not contribute to the construction of a sense of culture or to the development of the ICC in students since the cultural content contained in the textbooks was very limited.

242 Méndez (2005) has examined the representation of international and intercultural aspects in recent editions of fourteen English textbooks, used in secondary schools in Spain. The researcher has scrutinised the reading and listening sections of 174 units. The information has been gathered in a matrix specifically designed to analyse the cultural content taking into account cultural objectives, the methodology of the cultural component, and the valuation of culture. Each of these has 
been subdivided into secondary criteria. The findings have indicated that (a) the intercultural and international sociocultural content was only evidenced in 20 passages, and that 10 out of the 14 textbooks analysed included texts in which an English-speaking community was seen in relation to other cultures; (b) the connection between English-speaking countries and non-English speaking countries was exclusively made between Spain and the UK, and only 9 out of the 174 units that were studied make a connection between other non-English speaking countries and Spain; and (c) the relationship between Englishspeaking countries was discussed in 4 out of 174 units in which general distinctions were made between the US and the UK. Essentially, the UK has been the main focus of attention, hence excluding other Englishspeaking countries and other cultures. It is necessary to highlight an intercultural and international approach supported by a comparison and contrast of the tasks that complement the written or oral texts, with the proposal of the "double perspective" of societies (Kramsch, 1993). Textbook authors are advised to be aware of the complexity of the intercultural approach supported by explicit comparison and contrast without resorting to stereotypes.

Jiang (2010) has corroborated that the most widely used English textbook in China has played a decisive role in the variety of cultures that are taught and in the development of ICC. The anthropological culture (Scollon \& Scollon, 2001) has been adopted, which includes basic cultural knowledge, customs and habits, beliefs, morals and values; and ICC which covers cultural knowledge, the needed abilities to relate and interact with other cultures and with one's own culture, attitudes, communicative competence, and "critical cultural awareness, (savoir s'engager): an ability to evaluate, critically and on the basis of explicit criteria, perspectives, practices and products in one's own and other cultures and countries (Byram, Gribkova \& Starkey 1997, p. 9). The researcher has used Krippendorff's (1980) method of content analysis to determine the variety of cultures that are taught through textbooks by means of a set of criteria related to current affairs, realism, topics, task design and extra information to investigate how culture is taught through textbooks. The researcher has administered a questionnaire to 23 teachers and 202 students and interviewed the teachers. The study has concluded that textbooks are not designed to teach and learn culture, since no attention has been paid to local or universal culture. Also, tasks do not teach culture, stereotypes are not discussed, and ICC does not seem to be taken into account in the English teaching curriculum in China. The content of textbooks privileges the American and British cultures over the universal cultural diversity, 
and the concept of dynamism and transformation of cultures through the interaction with other cultures, since they are limited to teaching grammar and vocabulary.

Rico (2012) has determined how some adapted materials, selected from textbooks and based on principles, can develop the ICC in students whose predominant tongue is Spanish, in a university in the UK. His objectives have been evaluating books in the context of ICC, identifying some principles to adapt materials that develop ICC, and presenting some indicators of observation and a description of this competence in the development of materials. The study has been conducted in three cycles: an identification of the problem by administering a students' questionnaire, a culture bump activity, and an evaluation of textbooks; a design of an intervention strategy, and a strategy of evaluation with adapted materials; and an evaluation of the materials in use through students' observations, a review of a checklist and of their portfolios.

The researcher has relied on Byram, Nichol and Stevens' (2001) ICC theory, which has been defined as the set of social and psychological abilities of individuals to interact appropriately with other people from other cultural backgrounds that imply developing their knowledge, skills and epistemological and ethical postures. The researcher has also relied on Bennett's (1998) Development Model of Intercultural Sensitivity (DMIS), which is focused on the process of adaptation to a new culture (denial, defence, minimisation, acceptance, adaptation, and integration); and on Tomlinson's (2003) Text-Driven Approach (TDA) for developing experiential materials that promote reflection and communication - two essential abilities for developing the ICC.

The findings have shown that the materials which were adapted under the principles of experiential learning, the structured approach of intercultural learning, and the integration of intercultural learning into language learning have helped students to develop dimensions of the ICC: knowledge, awareness, abilities, attitudes, and competence. In particular, the development of the dimension of knowledge through activities that have provided students with information about cultures, self-knowledge, and the functioning of social groups - and the development of the cultural awareness through activities about the importance of language and culture lead to the promotion of the ICC.

Gómez (2015) has scrutinised the cultural content of three books, designed by foreign editorial companies and employed in English language teaching programmes by three universities in Bogotá, Colombia, to determine the extent to which they have developed the ICC. During the analysis, the subjects were classified under the following 
categories of superficial and deep culture: superficial culture involving celebrations, tourist attractions, achievements of famous people, local gastronomy, etc. The deep culture comprises intricate and invisible meanings of communities that reflect their own sociocultural norms, lifestyles, beliefs and values. They are multifaceted and dynamic and are sensitive to hegemony, exclusion, discrimination, and oppression, as well as to resistance, independence, inclusion, individuality, and justice (Hinkel, 2001). The results have demonstrated that these textbooks, which were mostly communicative, lacked elements of the deep culture that could contribute to the development of the ICC. In general, the subjects they presented belonged to the superficial culture and referred to static, congratulatory, and homogeneous notions. This study has concluded that teachers must consider teaching alternatives through the search, adaptation and, if possible, the development of materials by means through which students could be motivated toward the deep culture; so that instead of receiving a version of culture, they could adopt a critical position in the face of cultural realities such as transformative and heterogeneous ones.

Ajideh and Panahi (2016) have analysed cultural representations in textbooks used in Iran and their contribution to the development of the ICC in students. Their content analysis has been based on Ramírez and Hall's (1990) checklist, which has highlighted the amount of representation and presentation type given to various English-speaking countries in textbooks. The analysis has used two code schemes: one for visual representations and another for the sentences in the speaking sections. The number of illustrations and sentences contained in the different sections of the textbooks, and their respective direct or indirect references to culture have been evaluated. The study has revealed that textbook authors exclusively consider the source culture and do not present significant differences in dealing with cultures, since the source culture covered most of the references in illustrations and sentences in the speaking sections, while the target culture was scarcely referred to, which has been considered inappropriate for the development of the ICC.

All of these studies have provided theoretical background for the content analysis method and to the procedures for establishing the units of analysis (sampling, registration, and context), from the perspective of treatment and representation of culture to make sense of it and the development of the ICC. Likewise, the findings have recommended for authors to compare and contrast the cultural and intercultural complexity; and to challenge and resist the hegemony that is manifested in official curriculums. Such curriculums prescribe the 
type of culture that is taught through authorised textbooks, by means of producing some that favour the relationship between language and a transformative, heterogeneous and contentious culture, as a pillar for developing critical awareness, which leads to discerning the concealment or denial of the cultural differences and the multiplicity and complexity of universal cultures. Furthermore, it is very relevant to highlight Rico's (2012) study that has formulated some guiding principles for adapting textbooks, as mediators of ICC, in response to the needs of local contexts.

Literacy in the textbook. In this regard, researchers like Valencia (2006), Anvedsen (2012), and Zhang (2017) have examined the reading comprehension process or literacy in connection to the content of written passages and the reading comprehension activates proposed in English textbooks used in secondary education. The findings have first evinced that the development of contextualised reading comprehension activities foments literacy as the main skill to develop in English classes, and that the prominence of reading results from the exigency of the state exam (ICFES, its acronym in Spanish), as well as the expected performance of students in tertiary education. Second, the instrumental and controlling nature of the tasks focused on following instructions, locating, repeating or retaining information, and fostering conceptual development, do not promote abstraction, inference, or critical reading. Third, the systemic functional and linguistic constructs such as gender, register, meta-meanings, and the lexis-grammar system should be integrated to a learning theory, to the context and to the micro characteristics required for the development of literacy. These studies have remarked on the need for textbook authors to deem literacy as a sociocultural practice, which is localized within a historic and temporal space, and mediated by the English textbook, its written passages, iconography and reading comprehension activities that foster the construction of meaning based on previous experiences to let readers assume a critical stance of the text.

Representation of social subjects. The analysis of children as subjects of rights in the English textbooks conducted by Herrera (2012) has demonstrated three discursive strategies that show the way in 246 which textbooks tend to represent children as members of a society. Three main discourse strategies unveil the way EFL textbooks tend to represent children as members of society: gender and racial visibility, human being's passivity, and value- system inclusion. Even though the EFL textbooks regard some of the principles that support the educational discourse of children as subjects with rights, they still do not represent them as rights-holders but as passive subjects unaware of 
them. This study has remarked on the need for textbook authors to raise awareness about the representation they make of children as subjects of rights in the written passages, iconography and learning activities in English textbooks.

\section{Conclusions}

In summary, mainstream research of the English textbook reveal tensions, critiques and trends that are still latent in both national and international contexts. Content analysis of English textbooks, has underlined that the cultural information that they offer is incomplete, biased and distorted; and that the enormous human diversity and complexity is ignored, marginalised, silenced, or invisibilised. It can be inferred that these textbooks do not promote teaching and learning processes that contribute to the comprehension of universal cultural plurality. Thus, this has led us to think about English textbooks not only from the perspective of a developed product, based on the decisions made by the publishing industry and by local or foreign authors, but also from the perspective of critical interculturality to make possible the construction of criteria of being, knowledge and power that orient the development of the English textbook, and move away from a decontextualised toward a desirable contextualised one.

The former does not take into account the huge complexity and diversity of sociocultural and historical contexts of human plurality, focuses on the mechanical exercise of grammatical structures (Kramsch, 1993; Masuhara, Hann, Yi \& Tomlinson, 2008; Pulverness \& Tomlinson 2013; Rico, 2012; Tomlinson, Dat, Masuhara \& Rubdy, 2001; Tomlinson, 2013), which turns teachers' practices into repetitive and routinely (Guijarro, 2005; Kincheloe \& McLaren, 2015; Littlejohn, 2012; Martínez, 2008; Fernández-Reiris, 2006); responds to the dominant pedagogical and methodological assumptions and to the acritical use of methods and pedagogical strategies predetermined by centre countries (Allwright, 1981; Canagarajah, 2005a, 2005, 2002; Giroux \& Simon, 1988; Kincheloe, 1993; Kumaravadivelu, 2001; Prabhu, 1990); responds to economic interests of the publishing industry (Álvarez, 2008, Cárdenas, 2006; Giroux, 2001; González, 2012; Núñez, Téllez \& Castellanos (2013); Rico, 2012; Usma, 2009; Kumaravadivelu, 2001, Littlejohn, 2012); and is used as a subalternation instrument that preserves the idea of non-native speakers that belong to the subaltern community (Asian, Latin-American and African countries) unable to produce, but to consume knowledge. 
In contrast, the latter (the desirable contextualised one) is sensitive to universal diversity without distortions or biases, and that favours the development of people and groups according to their ethnic identities, social classes, gender, etc. In addition to this, the development of textbooks that are heterogeneous, oriented by emerging epistemologies and methodologies or derived from contexts and local communities with a bottom-up approach, urges students to reflect critically and to debate the numerous complexities, dissatisfactions, and human conflicts, and to propose alternative solutions to current and fluctuating problems.

Critical interculturality has been proposed as a decolonising alternative because it requires developing critical awareness regarding colonialism in English textbooks surrounding the colonialities of being, knowledge, and power. It also makes it possible to uncover inconsistencies and contradictions to transform realities with a basis for doing so, not only on the "reading of the word", but also on the "reading of the world" (Freire \& Macedo, 1987, p. 33) Critical interculturality, as a pedagogical decolonising alternative, pursues the construction of other ontological, epistemological and autonomous forms. They are equally important and valid, in a dialogic and respectful relationship, which is harmonious and symmetrical within the universal sociocultural diversity, recognising other voices and enunciation loci with autonomous authority.

\section{Limitations}

The present reflection article is limited by two aspects. First, the lack of studies regarding the representation of social subjects, the last category established in the state of the art, might be the second limitation since I wanted to remark not only on children's but also women's rights. In addition to this, the time frame may be one of the limitations since the related studies consulted included those published until early March 2018. In other words, the ones published within the period March December 2018 (time of this publication) are not considered. 


\section{References}

Ahmed, F. y Narcy-Combes, M. F. (2011). An analysis of textbooks from a cultural point of view. TESOL Journal, 5, 21-37

Aicega, D. (2007) Los libros de texto para la enseñanza de inglés: Una mirada crítica. Puertas Abiertas, 3(3), 99-102.

Ajideh, P., \& Panahi. M. (2016). An analysis of culture-related content in English textbooks for Iranian students entitled 'Prospect' and 'Vision' Series. International Journal of Language and Linguistics, 3(6), 87-93.

Aliakbari, M., \& Jamalvandi, B. (2013). Realization of culture in English textbooks in Chinese high school level. Journal of PanPacific Association of Applied Linguistics, 16(2), 89-101.

Aliakbari, M. (2004). The place of culture in the Iranian ELT textbooks in high school level. The proceedings of the 9th Conference of PanPacific Association of Applied Linguistics. Cheonan, Corea del Sur.

AL-Obaidi, L., (2015). The cultural aspects in the English textbook "Iraq opportunities" for intermediate stages. (Unpublished Master's thesis). Iraq: Middle East University.

Álvarez, J.A. (2008). Educational commercialism: ¿Is it overtaking EFL in Colombia? ASOCOPI Newsletter, p. 7.

Allwright, R. L. (1981). What do we want teaching materials for? ELT Journal, 36(1), 5-18.

Amalsaleh, E., Javid, F., \& Rahimi, A. (2010). The power of language and ELT textbooks. Procedia - Social and Behavioral Sciences, 9, 2052-2056.

Anvedsen, E. J. (2012). Textbooks, tasks and reading literacy: A close look at the teacher's resources in secondary school. (Unpublished Master's thesis). Trondheim: Norwegian University of Science and Technology NTNU.

Arias, L., Campo, E., \& Zuluaga, J. (2001). Apropos of accreditation: Coursebook evaluation and culture implementation in FLC. Folios, 13,1-13.

Baiqiang, T. (2008). Identifying and combating sexism in EFL textbooks- with a case study into China. Independent Researcher, $\mathrm{P}$ R China. 
Bataineih, A. (2009). An evaluation of the authentic socio-cultural elements in the prescribed English language textbooks of the secondary schools in Jordan. An-Najah University Journal for Research (Humanities) - B, 23(1), 289-324.

Bennett, M. J. (1998). Basic concepts of intercultural communication: Selected readings. Yarmouth: Intercultural-Press.

Borre, E. (1996). Libros de texto en el caleidoscopio. Pomares-Corredor, Barcelona, España: Editorial Trotta S. A.

Byram, M., Gribkova, B., \& Starkeu, H. (1997). Developing the intercultural dimension in language teaching a practical introduction for teachers. The Council of Europe, 1-35.

Byram, M., Nichols, A., \& Stevens, D. (Eds.) (2001). Developing intercultural competence in practice. Clevedon: Multilingual Matters.

Cárdenas, M. L. (2006). Bilingual Colombia: Are we ready for it? What is needed? Proceedings of the 19th Annual English Australia Education Conference. Retrieved from http://www.englishaustralia. com.au/ea_conference2006/proceedings/

Canagarajah, S. (2002). Globalization, methods, and practice in periphery classrooms. In. D. Block y D. Cameron (Eds.), Globalization and language teaching (pp.134-450). London, UK: Routledge.

Canagarajah, S. (2005a). Reconstructing local knowledge, reconfiguring language studies. In S. Canagarajah, (Ed). Reclaiming the Local in Language Policy and Practice. (pp. 3-24). Mahwah, NJ, USA: Lawrence Erlbaum Associates

Canagarajah, S. (2005b). Introduction. In S. Canagarajah (Ed.). Reclaiming the local in language policy and practice. Mahwah, NJ, USA: Lawrence Erlbaum Associates, xiii-xxx.

Choppin, A (1992). Les manuels scolaires: histoire et actualité [School handbooks: past and present]. París, Francia: Hachette Education, Collection Pédagogies pour demain.

250 Cortazzi, M., \& Jin, L. (1999). Cultural Mirrors: Materials and Methods in EFL Classroom. En E. Hinkel (Ed.), Culture in Second Language Teaching. (pp.169-206). Cambridge, UK: Cambridge University Press.

Craeynest, F. V. (2015). Gender representations in EFL textbooks: a quantitative and qualitative content analysis. (Unpublished Master's thesis). Ghent University, Flanders, Belgium. 
Cunningsworth, A. (1995). Choosing your coursebook. London: Heinemann.

Dabbagh, A. (2016). Gender representation under critical image analysis: The case of Iranian ELT textbooks. International Journal of English Language \& Translation Studies, 4(4), 39-52. Retrieved from www.eltsjournal.org

Datzman, B. (2013). Gender representation and EFL textbooks: A case study. Journal of The Faculty of Global Communication, 14, 1-13

Dehbozorgi, M., Amalsaleh, E., \& Kafipour, R. (2014). Exploring cultural content of three prominent EFL textbooks in Iran (a case study of American English File, Top Notch and Four Corners). Acta Didactica Napocensia, 7(1) 69-81.

De Sousa Santos, B. (2006). La Sociología de las Ausencias y la Sociología de las Emergencias: para una ecología de saberes [Sociology of absences and emergences: For an ecology of knowledge]. (pp.13-41). In: B. De Sousa, S. (Ed,), Renovar la teoría crítica y reinventar la emancipación social. (pp. 13-41). Buenos Aires, Argentina: CLACSO.

De Sousa Santos, B. (2010). Para descolonizar occidente. Más allá del pensamiento abismal. CLACSO, Prometeo Libros, Buenos Aires, 1-82. Retrieved from http://www.clacso.org.ar/librerialatinoamericana/inicio.php

Di Franco M. G., Siderac, S., \& Di Franco, N. (2007). Libros de texto: ¿saberes universales o descontextualizados? [Textbooks: Universal or decontextualised knowledge?]. Horizontes Educacionales, 12(1), 23-33.

Fairclough, N. (1989). Language and power. London: Longman.

Farzaneh, N., Kohandanib. M., \& Nejadansaric, D. (2014). A Textbook evaluation of socio-cultural contexts in Top Notch series. Procedia Social and Behavioral Sciences, 98, 472- 481.

Fernández-Reiris, A. (2006). La importancia de ser llamado "libro de texto". Hegemonía y control del currículo en el aula. Buenos Aires, Argentina: Niño y Dávila.

Freire, P. (1971), Pedagogy of the oppressed. New York: Herderand Herder.

Freire, P. (1993). Pedagogy of the oppressed. Harmondsworth: Penguin. 
Freire, P. \& Macedo, D. (1987). Reading the Word and the World. Boston, MA.: Bergins \& Garvey Publishers, Inc.

Fuentes, M. (2011). Conocimiento escolar y libros de texto. Una perspectiva intercultural. (Unpublished doctorate thesis). Madrid, España: Universidad Nacional de Educación a Distancia.

García, R. (1996). Los estudios del instituto Georg Eckert para la investigación internacional sobre libros de texto [Studies of the Georg Eckert institute for the international research on textbooks]. Didáctica de las Ciencias Experimentales y Sociales, 10, 3-9.

Garinger, D. (2002). Textbook selection for the ESL classroom. ERIC Digest. Retrieved from ERIC database. (EDO-FL-02-10).

Ghorbani, L. (2009). An investigation of the manifestation of sexism in EFL/ESL textbooks. Retrieved from Ehttps://eric. ed.gov/?id=ED505434

Giroux, H. A. (2001). Public spaces, private lives: beyond the culture of cynicism. New York; USA: Roman \& Littlefield.

Giroux, H., \& McLaren, P. (Eds.). (1994). Between borders: Pedagogy and the politics of cultural studies. New York: Routledge.

Giroux, H., \& Simon, R. (1988). Schooling, popular culture, and a pedagogy of possibility. Journal of Education, 170(1), 9-26.

Gómez, L. F. (2015). The cultural content in EFL textbooks and what teachers need to do about it. PROFILE Issues in Teachers' Professional Development, 17(2), 167-187. Retrieved from http:// dx.doi.org/10.15446/profile.v17n2.44272

González, A. (2012). On English language teaching and teacher education. Academic disagreements in a developing country. Retrieved from http://conference.pixel-online.net/edu_future2012/ common/download/Paper_pdf/524-SE76-FP-Gonzalez-FOE2012. pdf

Guijarro, J. R. (2005) La representación axiológica del género y la orientación sexual en libros de texto de inglés para Secundaria [Axiogical representation of gender and sexual orientation in the English textbook]. Porta Linguarum, 4,151-166.

Habib, A. (2014). An analysis of cultural load in English textbooks taught in Khyber Pakhtunkhwa, Pakistan. NUML Journal of Critical Inquiry, 12(2), 72-88. 
Hall, M. (2014). Gender representation in current EFL textbooks in Iranian secondary schools. Journal of Language Teaching and Research, 5(2), 253-261.

Hartman, Pat L. \& Elliot L. Judd. 1978. Sexism and TESOL materials. TESOL Quarterly, 12(4), 383-393.

Hill, P. (1980). Women in the world of ELT textbooks. EFL Gazette, 18/19, June/July.

Hinkel, E. (2001). Building awareness and practical skills to facilitate cross-cultural communication. In M. Celce-Murcia (Ed.), Teaching English as a second or foreign language (3rd ed., pp. 443-358). Boston, MA.: Heinle Cengage Learning.

Hussein Al Migdadi, M. (2008). The teaching of English and its culture in EFL contexts: A case study of English language instructors and students in the language centre at Al al-Bayt. (Unpublished doctorate thesis). Amán: The University of Jordan.

Jahan, A. (2012). Residual cultural imperialism in primary textbooks in Bangladesh: A critique of the English for today textbooks. English for today, 3, 73-94

Jiang, B. (2010). The role of college English textbooks in the teaching of culture in China. (Unpublished Doctorate Thesis). York, UK: University of York.

Kincheloe, J. L. (1993). Toward a critical politics of teacher thinking: Mapping the postmodern. Westport, CT, USA: Bergin \& Garvey.

Kincheloe, J. L., \& McLaren, P. (2015). Rethinking critical theory and qualitative research. In N.K. Denzin e Y. S. Lincoln. (Eds.). The Sage handbook of qualitative research. (3ed., pp. 241-315) Thousand Oaks, California, USA: Sage Publications

Kirkgöz, Y., \& Agcam, R. (2011). Exploring culture in locally published English textbooks for primary education in Turkey. CEPS Journal, 1(1), 153-167. Retrieved from URN: urn: nbn:de:0111-opus-65378

Kramsch, C. (1993). Context and culture in language teaching. Oxford, UK: Oxford University.

Krippendorff, K. (1980). Content analysis: an introduction to its methodology. California, USA: Sage Publications.

Kumaravadivelu, B. (1994). The post-method condition: (E)merging strategies for second/foreign language teaching. TESOL Quarterly, 28(1), pp. 27- 48. 
Kumaravadivelu, B. (2001). Postmethod pedagogy. TESOL Quarterly, 35(4),537-560.

Kumaravadivelu, B. (2003). Beyond methods: macro strategies for language teaching. New Haven; USA: Yale University Press.

Kumaravadivelu, B. (2006). Dangerous liaison: Globalization, empire and TESOL. En J. Edge (Ed.), (Re)locating TESOL in an age of empire (pp. 1-26). New York, USA: Palgrave Macmillan.

Kumaravadivelu, B. (2006a). TESOL Methods: changing tracks, challenging trends. TESOL Quarterly, 40, 59-81.

Kumaravadivelu, B. (2006b). Understanding language teaching. From method to post-metod. New Jersey, USA: Lawrence Erlbaum Associates, Inc., Publishers.

Kumaravadivelu, B. (2014). The Decolonial Option in English Teaching. Can the subaltern act? TESOL Quarterly, 14(1), 66-85.

Lander, E. (ed.) (2000) La colonialidad del saber: eurocentrismo y ciencias sociales: perspectivas latinoamericanas. Buenos Aires, Argentina: CLACSO.

Lee, J. F. (2014). A hidden curriculum in Japanese EFL textbooks: Gender representation. Linguistics and Education, 26, 39-53

Lee, J. F., \& Collins, P. (2008). Gender voices in Hong Kong English textbooks: Some past and current practices. Springer Science + Business Media, 59,127-137 doi: 10.1007/s11199-008-9414-6

Littlejohn, A. (2012). Language teaching materials and the (very) big picture. Electronic Journal of Foreign Language Teaching, 9(1), 283-297.

Martínez, B. (2008). Los libros de texto como práctica discursive [Textbooks as discursive practice]. Revista de la asociación de sociología de la educación, 1, 62-73.

Masuhara, H., Hann, M., Yi, Y., \& Tomlinson, B. (2008). Adult EFL courses, ELT Journal, 62(3), 294-312.

Méndez, M. C. (2005). International and intercultural issues in English teaching textbooks: The case of Spain. Intercultural Education, 16(1), 57-68.

Miekley, J. (2005). ESL textbook evaluation checklist. The Reading Matrix, 5(2), 2-9. 
Mora, D. (2009). Didáctica de las matemáticas. Desde una perspectiva crítica, investigativa, colaborativa y transformadora. La Paz, Bolivia: Editorial Instituto Internacional de Integración-Convenio Andrés Bello.

Mora, D., \& Unzueta, S. (2012). Estudio comparativo de los libros de texto de matemáticas, lenguaje y ciencias naturales de algunos países del Convenio Andrés Bello. La Paz, Bolivia: Editorial del Instituto Internacional de Integración-Convenio Andrés Bello.

Moya, C. (2008). Aproximación al concepto y tratamiento del texto escolar [An aproximation to the concept and treatment of the textbook]. Cuadernos de Lingüistica Hispánica, 11, 133-152.

Mukundan, J., \& Nimehchisalem, V. (2008). Gender representation in Malaysian secondary school English language textbooks. Indonesian Journal of English Language Teaching, 4(2), 155-173.

Ndura, E. (2010). ESL and cultural bias: An analysis of elementary through high school textbooks in the western United States of America. Language, Culture and Curriculum, 17(2), 143-153. doi: $10.1080 / 07908310408666689$

Negrín, M. (2009). Los manuales escolares como objeto de investigación [School handbooks as object of study]. Educación, Lenguaje y Sociedad, 6(6), 187-208.

Nguyen C. T. (2015). An evaluation of the textbook English 6: A case study from secondary schools in the Mekong Delta Provinces of Vietnam. (Unpublished Doctorate Thesis). South Yorkshire, England: University of Sheffield.

Nofall, M. \& Qawar, H. (2015). Gender representation in English language textbooks: Action pack 10. American Journal of Educational Science, 1(2), 14-18. Retrieved from http://www. aiscience.org/journal/ajes

Núñez, A., Téllez, M.F., \& Castellanos, J. (2013). Proposal for the Research Line Materials Development and Didactics Ascribed to the Research Group: Critical Pedagogy and Didactics for Social Transformation. Unpublished manuscript, School of Education, Universidad Externado de Colombia, Bogotá, Colombia. 
Pereira, A. (2013). Representações de gênero em livros didáticos de língua estrangeira: discursos gendrados e suas implicações para o ensino. En: A. Pereira. \& L. Gottheim, (Org.). Materiais didáticos para o ensino de língua estrangeira: processos de criação $e$ contextos de uso. Campinas: Mercado de Letras, 1, 113-146.

Porreca, K. (1984). Sexism in current ESL textbooks. TESOL Quarterly, 18(4) 705-724.

Prabhu, N. S. (1990). There is no best method-Why? TESOL Quarterly, 24, 161-176.

Pulverness, A., \& Tomlinson, B. (2013). Materials for cultural awareness. In B. Tomlinson (Ed.), Developing materials for language teaching (pp. 443-459). London: Bloomsbury Publishing Plc.

Ramírez, G. A. \& Hall, J. K. (1990). Language and culture in secondary level Spanish textbooks. Modern Language Journal, 74(1), 48-65.

Ramírez, T. (2002). El texto escolar como objeto de reflexión e investigación [The school textbook as object of reflection and research]. Docencia Universitaria, 3(1), 101-124.

Reimann, A. (2009). A Critical analysis of cultural content in EFL Materials. Journal of the Faculty of International Studies, Utsunomiya University, 85-101. Retrieved from https://uuair.lib. utsunomiya-u.ac.jp/dspace/.../28-8-reimann.pdf

Rico, C. (2012). Language teaching materials as mediators for ICC development: A challenge for materials developers. Signo y Pensamiento, 30, 130-154.

Rifkin, B. (1998). Gender representations in foreign language textbooks: A case study of textbooks of Russian. The Modern Language Journal, 82(2), 217-236.

Rimani. F., \& Soleimani, F. (2012). The manifestation of culture in Iranian and Turkish high school English text books. Academic Research International, 2(3), 646-656.

Scollon, R. \& Scollon, S. (2001). Intercultural communication: A discourse approach. Oxford, U.K.: Blackwell Publishers Ltd. 108 Cowley Road.

Syarifuddin, (2014). Sexism in EFL textbooks used in Indonesian schools. Lingua, 9(1), 62-74. 
Thang, S. (2009). Addressing culture in EFL classrooms: The challenge of shifting from a traditional to an intercultural Stance. Electronic Journal of Foreign Language Teaching, 6(1), 63-76.

Tomlinson, B. (Ed.) (2003). Developing materials for language teaching. London, UK: Continuum Press.

Tomlinson, B. (2013). Developing materials for language teaching. London, UK: Bloomsbury Publishing Plc.

Tomlinson, B., Dat, B., Masuhara, H. \& Rubdy, R. (2001). ELT courses for adults. ELT Journal, 55(1), 80-101.

Torres, S. J. (1993). Las culturas negadas y silenciadas en el currículum. En Cuadernos de Pedagogía, 217, 60-66.

Usma, J. (2009). Education and language policy in Colombia: Exploring processes of inclusion, exclusion, and stratification in times of global reform. PROFILE Issues in Teachers' Professional Development, 1, 123-141.

Valencia, S. (2006). Literacy practices, texts, and talk around texts: English language teaching developments in Colombia. Colombian Applied Linguistics Journal, 8, 7-37.

Varón, M. E. (2009). Componente cultural, libros de texto y enseñanza del inglés como lengua extranjera [Cultural component, textbooks and teaching of English as a foreign language]. Forma y Función, 22(1), 95-124. Bogotá, Colombia.

Villalaín, J. (2001). El proyecto MANES: Una aproximación sistemática al estudio de los manuales escolares de los siglos XIX y XX. Revista Educación y Pedagogía, 13(29-30), 85-91

Voloshinov, V. (1992) El marxismo y la filosofia del lenguaje. Madrid, España: Alianza.

Walsh, C. (2009). Interculturalidad crítica y educación intercultural [Critical interculturality and education]. Artículo ampliación de la ponencia presentada en el Seminario "Interculturalidad y Educación Intercultural", organizado por el Instituto Internacional de Integración del Convenio Andrés Bello, La Paz, 9-11 de marzo de 2009. pp.1-18.

Xiao, J. (2010). Cultural content of an in-use EFL textbook in English major students' attitudes and perceptions towards culture learning at Jinagxi University of Science and Technology. (Unpublished Doctorate Thesis). China: Prince of Songkla University. 
Yassine, S. (2012). Culture issues, ideology and otherness in EFL textbooks: A social, semiotic, multimodal approach (Unpublished Doctorate Thesis). Algeria: Mouloud Mammeri University of TiziOuzou.

Zhang, X. (2017). A critical review of literature on English language teaching textbook evaluation: What systemic functional linguistics can offer. Journal of Language and $\quad C u l t u r$ al Education, 5(1), 78-102. 


\section{Author}

*Astrid Núñez-Pardo holds an M.A. in Education, a Specialisation in International Economics, a B.A. in Hotel and Tourism Business Management from Universidad Externado de Colombia, a Diploma in Linguistic Studies from University of Essex, Colchester, England, and on Child Rights Classroom and School Management from Lund University, Sweden. She is pursuing her $\mathrm{PhD}$ in Education at UPTC, Colombia, is a professor for the Master's Programme in Education and the leader of the research line on Materials Development and Didactics at this university, acknowledged by COLCIENCIAS 